\title{
ISOLATION AND CHARACTERIZATION OF BLIAI, AN ISOSCHIZOMER OF CLAI FROM BACILLUS LICHENIFORMIS
}

\author{
Jocelei Maria Chies ${ }^{1,2, *}$; Ana Christina de Oliveira Diass ${ }^{1}$; Hélio Mauro Moreira Maia ${ }^{\dagger}$, Luis Paulo da Silva Braga ${ }^{1}$; \\ Spartaco Astolfi-Filho ${ }^{2,3}$
}

${ }^{1}$ Centro de Biotecnologia, Universidade Federal do Rio Grande do Sul, Porto Alegre, RS, Brasil; ${ }^{2}$ Curso de Pós-Graduação em Biologia Molecular, Universidade de Brasília, Brasília, DF, Brasil; ${ }^{3}$ Centro de Apoio Multidisciplinar, Universidade Federal do Amazonas, Manaus, AM, Brasil; 'In Memorian

Submitted: July 21, 2005; Returned to authors for corrections: March 09, 2006; Approved: July 18, 2006

\begin{abstract}
The restriction endonuclease BliAI, an isoschizomer of ClaI, which recognizes the sequence 5'- AT $\downarrow$ CGAT - 3', was purified from a natural isolate identified as Bacillus licheniformis. The restriction endonuclease was isolated from cell extracts using single-step purification by phosphocellulose column chromatography. The restriction endonuclease is active at $37^{\circ} \mathrm{C}$ and over a wide range of $\mathrm{pH}$ and salt concentration. The molecular weight of the purified restriction enzyme is consistent with a value of $39 \mathrm{kDa}$.
\end{abstract}

Key words: type II restriction endonuclease, BliAI, ClaI, isoschizomers, Bacillus licheniformis

\section{INTRODUCTION}

Type II restriction-modification (R-M) systems are pairs of enzymes: one, a restriction endonuclease (RE); the other, a methyltransferase, with opposing intracellular activities $(21,30)$. The RE recognizes specific sequences on DNA and cleaves it at a particular site, whereas the cognate methyltransferase modifies DNA within the same recognition sequence, thereby preventing cleavage by the RE. By possessing these two opposing enzymes, bacteria may protect their own DNA and still degrade foreign DNA, thereby limiting the spread of invading DNA molecules within the bacterial population $(2,8,13,29)$. In addition, DNA methylation may be involved in the regulation of chromosomal DNA replication $(14,27)$ and gene expression $(5,10)$, transposon movement $(20)$, or DNA mismatch repair (15).

Restriction endonucleases play a crucial role in the control of phage propagation and lateral gene spreading in natural environments. Type II restriction endonucleases activities of Bacillus licheniformis strains have been detected in many environments and analyzed by conventional techniques (22).
The present study relates the characterization of an isoschizomer of $\mathrm{Cla}$ I from B. licheniformis, BliAI, which recognizes the 6-base pair interrupted palindrome $5^{\prime}$ - AT $\downarrow$ CGAT $-3^{\prime}$, and cleaves double-stranded DNA after the first $\mathrm{T}$ in the sequence, producing 2 -nucleotide long 5 '-protruding ends.

\section{MATERIALS AND METHODS}

\section{Bacterial strain isolation and cultivation}

B. licheniformis bacteria were isolated from samples of the water collected in the Amazon river on the outskirts of the city of Manaus $\left(60^{\circ} 1^{\prime} \mathrm{W}, 3^{\circ} 7^{\prime} \mathrm{S}\right)$. At the time of the sampling the temperature was $36^{\circ} \mathrm{C}$. Bacterial isolation (colony isolation), growth, harvesting, washing and storage have been described elsewhere (6,7).

\section{Identification of bacterial isolates}

Bacterial identification was performed by small-subunit rRNA gene (SSUrDNA) DNA sequencing (17). The bacterial genomic DNA was purified using a QIAGEN Genomic Tip 20/G (QIAGEN$\mathrm{GmbH}$ ), yielding $13 \mu \mathrm{g}$ from $2 \mathrm{~mL}$. The SSU rDNA was amplified

*Corresponding Author. Mailing address: Cenbiot-UFRGS. Av. Bento Gonçalves. 9.500. Caixa Postal 15005, Porto Alegre, RS, Brasil. Telefax: (+5551) 3316-6092. E-mail: joceleichies@ terra.com.br 
by 30 cycles of PCR using primers 530F (5' TGACTG ACT GAG TGC CAG CMG CCG CGG 3') and 1492R (5' TGA CTG ACT GAG AGCTCT ACC TTG TTACGM YTT3') (Invitrogen - USA) (4). The PCR mixture $(50 \mu \mathrm{L})$ contained $1 \mu \mathrm{L}$ of template DNA, $50 \mathrm{mM}$ Tris $\mathrm{pH} 8.4,500 \mu \mathrm{g} / \mathrm{mL}$ of BSA, $1.5 \mathrm{mM} \mathrm{MgCl}_{2}, 250 \mu \mathrm{M}$ dNTPs, $400 \mathrm{nM}$ of each primer, and 2.5U of Taq DNA Polymerase (CenBiot Enzimas - BR). All reagents were combined and heated at $94^{\circ} \mathrm{C}$ for $2 \mathrm{~min}$. Thirty-five cycles of PCR were performed in a PTC 200 thermocycler (MJ Research, USA) as follows: $94^{\circ} \mathrm{C}$ for $2 \mathrm{~min}, 50^{\circ} \mathrm{C}$ for 30 seconds, and $72^{\circ} \mathrm{C}$ for $2 \mathrm{~min}$; followed by a final elongation at $72^{\circ} \mathrm{C}$ for $2 \mathrm{~min}$. The PCR products were directly sequenced with a DYEnamic ET Dye Terminator Cycle Sequencing Kit in the MegaBACE 1000 System (Amersham Pharmacia Biotech - UK), using 530F and 1492R primers. PCR amplification and amplicon DNA sequencing were repeated five times in order to confirm the results. The sequences were analyzed by multiple sequence alignments using the computer program Clustal X (11). The consensus sequence derived from the multiple alignment was used to search the GenBank database using BLAST (1).

\section{Purification procedure}

Cells from a log-phase culture were disrupted by three passes through a French press. The purification was based on a protocol described elsewhere (9) with minor modifications. Cell debris was first removed by centrifugation. Streptomycin sulfate was then slowly added to the resulting supernatant to a final concentration of $1.8 \%$ in order to remove DNA, which was then centrifuged at $28,000 \times \mathrm{g}$ for $1 \mathrm{~h}$ at $4^{\circ} \mathrm{C}$. The supernatant was dialyzed against PC Buffer $\left(100 \mathrm{mM} \mathrm{K} \mathrm{HPO}_{4} / \mathrm{KH}_{2} \mathrm{PO}_{4} \mathrm{pH} 7.5\right.$, containing $0.1 \mathrm{mM}$ EDTA, $10 \mathrm{mM} \beta$-mercaptoethanol ( $\beta$-ME), $150 \mathrm{mM} \mathrm{NaCl}$, and $0.02 \mathrm{mM}$ phenyl-methyl-sulfonyl-fluoride (PMSF) and clarified at 28,000 $\mathrm{g}$ for $20 \mathrm{~min}$ at $4^{\circ} \mathrm{C}$. The clear supernatant was loaded on a $2 \times 12 \mathrm{~cm}$ phosphocellulose column (P11, Whatman Inc, USA) previously equilibrated with PC buffer, washed with three column volumes with same buffer and eluted with a $\mathrm{NaCl}$ linear gradient $(0-600 \mathrm{mM})$. Active fractions were identified by digestion of bacteriophage $\lambda$ DNA in "One for all" buffer (Pharmacia, UK)

Fractions showing restriction activity were pooled out and dialyzed into long-term storage buffer (50\% glycerol/PC buffer containing $50 \mathrm{mM} \mathrm{NaCl}$ ), and stored at $-20^{\circ} \mathrm{C}$.

\section{Molecular weight determination}

The molecular weight of the enzyme was estimated by gel filtration chromatography using an FPLC Superdex-75 HR 10/ 30 column (Amersham Pharmacia Biotech) previously calibrated with the following molecular weight markers: $65 \mathrm{kDa}$, bovine serum albumin; $45 \mathrm{kDa}$, ovalbumin; $36 \mathrm{kDa}$, glyceraldehyde 3phosphate dehydrogenase; $29 \mathrm{kDa}$, bovine carbonic anhydrase; $24 \mathrm{kDa}$ trypsinogen; $12.4 \mathrm{kDa}$, horse heart cytochrome and 6.5 $\mathrm{kDa}$ aprotinin.

\section{Enzyme characterization, quality control tests, and restriction} cleavage analysis

The optimum salt concentration, $\mathrm{pH}$ and temperature were determined for the purified enzyme preparation with a set of SuRE/Cut buffers for restriction enzymes, namely A, B, H, L and $\mathrm{M}$ (Boehringer Mannheim), using a standard protocol (3) in the presence of $0.5 \mu \mathrm{g}$ of $\lambda$ DNA and $1 \mathrm{U}$ of enzyme. One unit of enzyme activity is defined as the amount of restriction endonuclease required to totally digest $1 \mu \mathrm{g}$ of $\lambda$ DNA in $1 \mathrm{~h}$ at $37^{\circ} \mathrm{C}$ in a reaction volume of $50 \mu 1$. The purity of the endonuclease preparation with respect to "non-specificnucleases" was evaluated by "over-digestion" tests. Restriction cleavage analysis was performed by the digestion of DNAs of bacteriophages $\lambda$ and $\phi X 174$ and plasmids pBR322 and pCIneo, using the same set of SuRE/Cut buffers as described above. DNA fragments were analyzed by gel electrophoresis (24). A commercial enzyme ClaI (Invitrogen) was used as control.

\section{Determination of the cleavage site of BliAI using pCRBlunt+ mec A DNA}

The DNA of a pCRBlunt plasmid plus a stretch of 245 nucleotides was inserted in the specific site located at the multiple cloning site. The stretch of the mecA gene from Staphylococcus aureus used was the nucleotide between 1106 and 1351 (23). The purified restriction enzyme in the presence of $\mathrm{Mg}^{2+}$ at $37^{\circ} \mathrm{C}$ in SuRE/Cut buffer $\mathrm{H}$ for 1 hour, was used in order to determine the cleavage site of this restriction enzyme, and sequencing of the digested DNA solution was performed by the chain termination method (25) using ${ }^{33} \mathrm{P}$-dNTPs and the Thermo Sequenase radiolabeled terminator cycle sequencing Kit (Amersham Pharmacia Biotech - UK). The primers utilized were as follows: -T7 Promoter Primer, 5'-TAA TAC CAC TCA CTATAG GG-3' (Novagen Cat n ${ }^{\circ}$ 69348-3) and M13 reverse, 5'CAG GAAACA GCT ATG AC-3 “ (Invitrogen Cat n ${ }^{\circ} 13432013$ ). The same protocols for DNA cleavage and sequencing were performed using commercially available $\mathrm{ClaI}$ (Invitrogen).

\section{RESULTS AND DISCUSSION}

Sequencing of SSUrDNA and sequence alignments to other 16S rRNA coding DNA sequences revealed 99\% identity with B. liqueniformis $16 \mathrm{~S}$ ribosomal RNA gene, partial sequence GenBank accession D31739. Bacillus licheniformis [gi:497790].

The molecular weigh of the purified restriction enzyme was estimated by gel filtration and the elution profile was consistent with a value of $39 \mathrm{kDa}$ for the native protein. The optimum $\mathrm{pH}$, temperature, and salt concentration were estimated to be, respectively, 7.5 at $37^{\circ} \mathrm{C}$ in SuRE/Cut Buffer $\mathrm{H}$ (50 mM Tris$\mathrm{HCl}$, containing, $10 \mathrm{mM} \mathrm{MgCl}, 100 \mathrm{mM} \mathrm{NaCl}$, and $1 \mathrm{mM}$ dithioerythritol). Similarly, at pH 8.0 in the above buffer, activity 
was essentially the same as well in SuRE/Cut Buffer M at pH 7.5 at $37^{\circ} \mathrm{C}$

One unit of $\mathrm{BliAI}$ is defined as the amount of enzyme required to cleave $1 \mu \mathrm{g}$ of $\lambda$ DNA in a suitable buffer in one hour at $37^{\circ} \mathrm{C}$ in a $50-\mu \mathrm{L}$ reaction.

The restriction fragment patterns produced by the purified enzyme and commercially available ClaI analyzed by the digestion of DNAs of bacteriophages $\lambda$ and $\phi X 174$ and plasmids pBR322 and pCI-neo were compared to allow the determination of the recognition sequence of the $B$. licheniformis RE. It was found that for $\lambda$ DNA there were 16 restriction fragments, and for the substrates $\phi X 174$, pBR322 and pCI-neo there were zero, 1 and 2 restriction fragments, respectively (Fig. 1). The cleavage restriction patterns are identical to the one seen with ClaI, suggesting that the unknown restriction enzyme recognizes the same DNA sequence as $\mathrm{Cla}$ I does.

The primers designed to anneal specifically either to a DNA sequence starting from nucleotide 205 or from nucleotide 400 of the original plasmid pCR Blunt, allow the synthesis of single-stranded DNA of different lengths. This stretch of DNA sequence, part of the mecA gene from $S$. aureus, was chosen

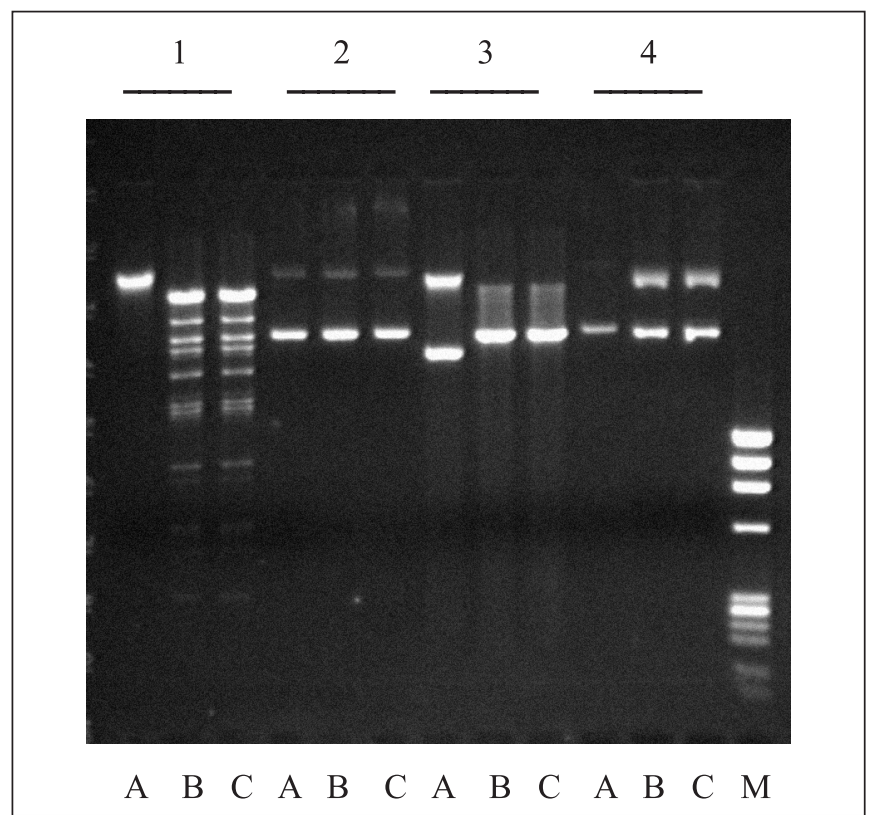

Figure 1. Agarose gel electrophoresis of restriction fragments produced by cleavage of four DNA substrates. The cleaved DNAs were separated by electrophoresis on $0.8 \%$ agarose gel and visualized under UV after ethidium bromide staining. (1) $\lambda$ phage DNA, (2) $\phi X 174$ phage DNA, (3) pBR322 DNA and (4) pCI-neo DNA. (A) undigested DNA, (B) BliAI and (C) ClaI (invitrogen-USA) (M) $1 \mu \mathrm{g} \phi \mathrm{X} 174 / \mathrm{Hae} I \mathrm{II}$ markers (G1761Promega). because it possesses only one ClaI digestion site. The nucleotide sequence determination by the dideoxy chain termination method of the amplified fragments, produced by pCR Blunt+mecA plasmid DNA digestion with the $B$. licheniformis enzyme and ClaI, clearly showed that $5^{\prime}$ AT $\downarrow$ CGAT - 3 is the recognition sequence (Fig. 2). The DNA sequencing results confirmed the restriction cleavage analysis

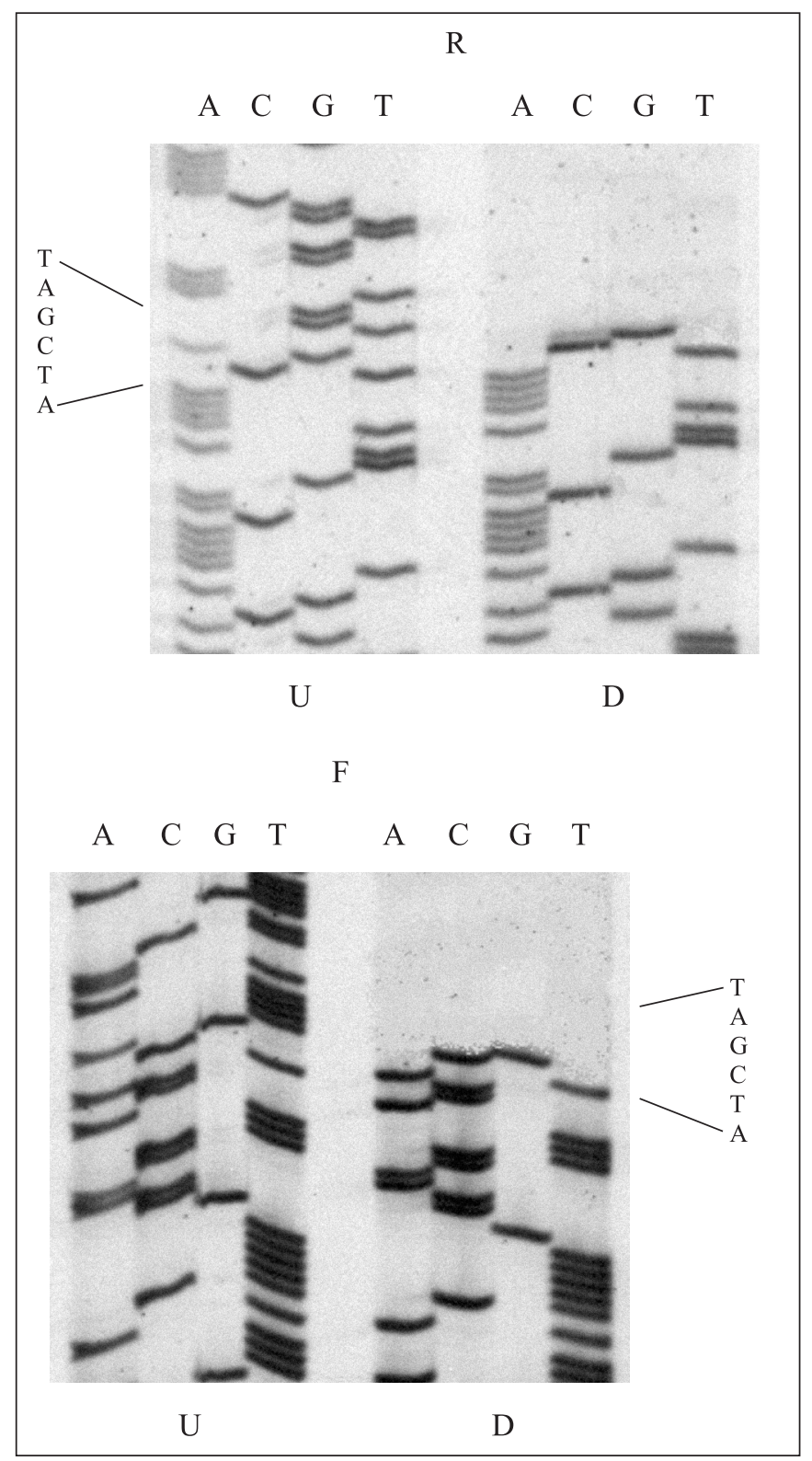

Figure 2. DNA sequencing gel showing the labeled product, approximately 20 bases either side of the putative cut site of BliAI. R and F are the amplification products using, respectively, the reverse and forward primers. $U$ and $D$ are the same amplification products undigested and digested, respectively. 
and strongly suggest that the B. licheniformis restriction enzyme is an isoschizomer of ClaI.

The restriction endonuclease $C l a \mathrm{I}$ was first described in 1981 (26). The first communication of an isoschizomer of $\mathrm{ClaI}$ from B. licheniformis Bli41I was described eight years later (19), at the same time that another isoschizomer of $C l a \mathrm{I}$ from $B$. licheniformis Bli86I was described (12). Soon after other isoschizomers of this same enzyme were also described, BliRI in 1992 (16) and Bli576I and Bli585I in 1995 (18). However, since 1995, no ClaI isoschizomers from B. licheniformis have been described.

To date, 102 isoschizomers of this restriction endonuclease have been found in many bacterial genera, 44 of them in the genus Bacillus, five in the species B. licheniformis. They are listed on the web server REBASE (http://rebase.neb.com) including nine commercially available from 17 different suppliers.

Apart from the five $C l a \mathrm{I}$ isoschizomers found in the species B. licheniformis, there are eight more type II RE isoschizomers described in this bacterial species, none as a prototype.

The type-II restriction enzyme reported here was named BliAI, Bli as recommended by the official nomenclature (28), and the intervening letter " $A$ " for Amazon as suggested by Dr. Richard Roberts, since this bacteria was found in the Amazon River.

The BliAI enzyme has been deposited on the official REBASE web site (www//http.rebase.neb.com) under enzyme number \# 6509.

\section{RESUMO}

\section{Isolamento e caracterização de BliAI, um isoesquisômero de ClaI de Bacillus licheniformis}

A endonuclease de restrição BliAI, um isoesquisômero de $C l a I$, que reconhece a sequiência 5' - AT $\downarrow$ CGAT - 3', foi purificada de um isolado natural identificado como Bacillus licheniformis. A endonuclease de restrição em questão foi isolada a partir de um extrato celular em um único passo cromatográfico utilizando uma coluna contendo a resina fosfocelulose. A endonuclease de restrição é ativa à $37^{\circ} \mathrm{C}$ e em uma ampla escala de $\mathrm{pH}$ e concentração de sais. O peso molecular da enzima purificada corresponde a um valor de $\mathrm{kDa} 39$.

Palavras-chave: Endonuclease de restrição do tipo II, isoesquisômero, Bacillus licheniformis

\section{REFERENCES}

1. Altschul, S.F.; Madden, T.L.; Schäffer, A.A.; Zhang, J.; Zhang, Z.; Miller, W.; Lipman, D.J. Gapped. BLAST and PSI-BLAST: A new generation of protein database search programs. Nucleic Acids Res., 25, 3389-3402, 1997
2. Arber, W.; Dussoix, D. Host specificity of DNA produced by Escherichia coli: I. host controlled modification of bacteriophage $\lambda$. J. Mol. Biol., 5, 18-36, 1962.

3. Biochemical Catalog. 1. Molecular Biology. Boehringer Mannheim. GmbH, Germany, 1998, p.131-132.

4. Borneman, J.; Triplett, E.W. Molecular microbial diversity in soils from Eastern Amazonia: evidence from unusual microbial population shifts associated with deforestation. Appl. Environ. Microbiol., 63, 2647-2653, 1997.

5. Braaten, B.A.; Nou, X.; Kaltenbach, L.S.; Low, D.A. Methylation patterns in pap regulatory DNA control pyelonephritis-associated pili phase variation in E. coli. Cell., 76, 577-588, 1994.

6. Chies, J.M.; Dias, A.C.O.; Maia, H.M.M.; Astolfi-Filho, S. BanAI a new isoschizomer of the type II restriction endonuclease HaeIII discovered in a Bacillus anthracis isolate from Amazon Basin. FEMS Microbiol Lett., 215, 97-101, 2002.

7. Chies, J.M.; Dias, A.C.O.; Maia, H.M.M.; Astolfi-Filho, S. BpuAmI; a novel SacI neoschizomer from Bacillus pumilus discovered in an isolate from Amazon Basin, recognizing 5'-GAG $\downarrow$ CTC-3'. Braz. J. Microbiol., 37, 96-100, 2006.

8. Dussoix, D.; Arber, W. Host specificity of DNA produced by Escherichia coli: II. Control over acceptance of DNA from infecting phage A. J. Mol. Biol., 5, 37-49, 1962.

9. Greene, J.P.; Heineker, H.I.; Bolivar, F.; Rodriguez, R.I.; Betlach, M.C.; Covarrubias, A.A.; Backman, K.; Russel, D.J.; Tait, R.; Boyer, H.W. A general method for the purification of restriction enzymes. Nucleic Acids Res., 5, 2373-2380, 1978.

10. Heithoff, D.M.; Sinsheimer, R.L.; Low, D.A.; Mahan, M.J. An essential role for DNA adenine methylation in bacterial virulence. Science, 284, 967-970, 1999.

11. Jeanmougin, F.; Thompson, J.D.; Gouy, M.; Higgins, D.G.; Gibson, T.J. The CLUSTAL-X windows interface: flexible strategies for multiple sequence alignment aided by quality analysis tools. Nucleic Acids Res., 24, 4876-4882, 1997.

12. Kramarov, V.M.; Skrypina, N.A.; Smolianinov, V.V.; Smirnov, V.V.; Reznik, S.R.; Sorokulova, I.B.; Matvienko, N.I. New producers of site-specific endonucleases from microorganisms of the Bacillus genus. Mol. Gen. Mikrobiol. Virusol., 6, 42-45, 1989.

13. Kuhnlein, U.; Arber, W. Host specificity of DNA produced by Escherichia coli. XV. The role of nucleotide methylation in in vitro B-specific modification. J. Mol. Biol., 63, 9-19, 1972.

14. Messer, W.; Noyer-Weidner, M. Timing and targeting: the biological functions of Dam methylation in E. coli. Cell., 54, 735-737, 1988.

15. Modrich, P.; Methyl-directed DNA mismatch correction. J. Biol. Chem., 264, 6597-6600, 1989.

16. Mushtaq, R.; Naeem, S.; Riazuddin, S. May 4 Unpublished observations, REBASE, http://rebase.neb.com, 1992.

17. Pace, N.R.; Sahl, D.A.; Lane, D.J.; Olsen, G.J. The analysis of natural microbial population by ribosomal RNA sequences. Adv. Microb. Ecol., 9, 1-55, 1986.

18. Parini, C.; Fortina, M.G. Site-specific restriction endonucleases in Bacilus licheniformis. FEMS Microbiol. Lett., 132, 285-289, 1995.

19. Repin, V.E.; Rechkunova, N.I.; Degtyarev, S.K.; Hachaturyan, A.A.; Afrikyan, E.K. Aerobic spore-forming bacteria as producers of restriction endonucleases. Biol. J. Armenia, 42, 969-972, 1989.

20. Roberts, D.; Hoopes, B.C.; McClure, W.R.; Kleckner, N. IS10 transposition is regulated by DNA adenine methylation. Cell., 43, 117-130, 1985.

21. Roberts, R.J.; Halford, S.E. Type II restriction endonucleases In: Nucleases Linn, S.M., Lloyd, R.S.; Roberts, R.J. (eds.), Cold Spring Harbor Laboratory Press, Cold Spring Harbor, New York, NY, 1993, p.35-88.

22. Roberts, R.J.; Vincze, T.; Posfai, J.; Macelis, D. Restriction Enzymes and DNA methyltransferases. Nucleic Acids Res., 33, D230-D232, 2005. 
23. Ryffel, C.; Tesch, W.; Bich-Machin, I.; Barberis-Maino, L.; Kayser, F.H.; Berger-Bachi, B. Sequence comparison of mecA genes isolated from methicilin-resistant $S$. aureus and S. epidermidis. Gene, 94, 137-138, 1990.

24. Sambrook, J.; Fritsch, E.F.; Maniatis, T. In: Molecular Cloning: A Laboratory Manual. $2^{\text {nd }}$ Edn. Cold Spring Harbor Laboratory Press, Cold Spring Harbor, New York, NY. 1989.

25. Sanger, F.; Nicklen, S.; Coulson, A.R. DNA-sequencing with chainterminating inhibitors. Proc. Natl. Acad. Sci. USA, 74, 5463-5467, 1977.

26. Mayer, H.; Grosschedl, R.; Schutte, H.; Hobom, G. ClaI, a new restriction endonuclease from Caryophanon latum L. Nucleic Acids Res., 9, 4833-4845, 1981.
27. Smith, D.W.; Garland, A.M.; Herman, G.; Enns, R.E.; Baker, T.A.; Zyskind, J.W. Importance of state of methylation of oriC GATC sites in initiation of DNA replication in Escherichia coli. EMBO J., 4, 1319-1326, 1985.

28. Smith, H.O.; Nathans, D. A suggested nomenclature for bacterial host modification and restriction systems and their enzymes. $J$. Mol. Biol., 81, 419-423. 1973.

29. Smith, J.D.; Arber, W.; Kuhnlein, U. Host specificity of DNA produced by Escherichia coli. XIV. The role of nucleotide methylation in in vivo B-specific modification. J. Mol. Biol., 63, 1-8, 1972.

30. Wilson, G.G.; Murray, N.E. Restriction and modification systems. Апnи. Rev. Genet., 25, 585-627, 1991. 